\title{
Tipologi Inovasi Pelayanan Pajak Daerah Melalui EPPSON di BPPKAD Kota Surakarta
}

\author{
${ }^{1}$ Evita Dina Pratiwi, ${ }^{2}$ Kristina Setyowati \\ ${ }^{1}$ Universitas Sebelas Maret Surakarta, Indonesia; evitadina61@student.uns.ac.id \\ ${ }^{2}$ Universitas Sebelas Maret Surakarta, Indonesia; kristina@staff.uns.ac.id
}

\begin{abstract}
Tax is the main source of financing for state expenditures in order to improve people's welfare. Given the important role of taxes in the country's economy, in fact there are still many problems and obstacles that must be faced in collecting local taxes in Indonesia. One of the efforts of the Surakarta City government to overcome this problem is through innovative technology-based local tax services in the form of the Electronic Solo Destination Tax Payment (EPPSON) feature. This study aims to determine the typology of local tax service innovation through EPPSON by using the typology dimension of innovation according to Perry, which consists of product innovation, service innovation, process innovation, conceptual innovation, policy innovation and systemic innovation. The research method used in this research is descriptive qualitative, data collection techniques through interviews, observation and documentation. The results showed that in its implementation, EPPSON innovation had met the criteria of product innovation, service innovation, process innovation, and systemic innovation. In addition, the EPPSON innovation has helped overcome local tax problems before the creation of this innovation.
\end{abstract}

Keywords: Local Government, Public Services, Innovation, EPPSON, Local Taxes

\section{Pendahuluan}

Pajak menjadi sumber utama pembiayaan pengeluaran negara untuk meningkatkan kesejahteraan masyarakat. Landasan konstitusional pemungutan Pajak terdapat dalam Pasal 23A Undang-Undang Dasar Negara Republik Indonesia Tahun 1945 yang mengalami perubahan keempat menjadi Undang-Undang Nomor 16 Tahun 2009 Tentang Ketentuan Umum dan Tata Cara Perpajakan, yang menempatkan perpajakan sebagai salah satu perwujudan kenegaraan, ditegaskan bahwa penempatan beban kepada rakyat, seperti pajak dan pungutan lain yang bersifat memaksa diatur dengan Undang-Undang. Dengan demikian, pemungutan pajak harus didasarkan pada Undang-Undang. Berdasarkan lembaga pemungutannya, pajak dibedakan menjadi pajak pusat dan pajak daerah. Pajak pusat adalah pajak yang dipungut dan dikelola oleh Pemerintah Pusat, dalam hal ini sebagian besar dikelola oleh Direktorat Jenderal Pajak (DJP). Sedangkan pajak daerah adalah pajak yang dipungut dan dikelola oleh Pemerintah Daerah baik tingkat provinsi maupun kabupaten/kota. Meski lembaga pemungutan dan pengelolaannya berbeda, namun pajak pusat dan pajak daerah merupakan satu sinergi dalam membangun Indonesia secara nasional dari Sabang sampai Merauke. 
Berdasarkan UU No 28 Tahun 2009 Tentang Pajak Daerah dan Retribusi Daerah, terjadi perubahan dalam pengelolaan pajak pusat dan daerah. Yaitu pengalihan Pajak Bumi dan Bangunan Perdesaaan dan Perkotaan (PBB P2) serta Bea Perolehan Hak atas Tanah dan Bangunan (BPHTP) dari yang sebelumnya termasuk pajak pusat beralih menjadi pajak daerah. Tujuan dari pengalihan pengelolaan PBB P2 menjadi pajak daerah adalah untuk memberikan kewenangan yang lebih besar kepada daerah dengan memperluas basis pajak daerah dan penetapan tarif, sehingga diharapkan dapat meningkatkan Pendapatan Asli Daerah (PAD). Menurut (Horota, Riani, \& Marbun, 2017), Pendapatan Asli Daerah (PAD) dapat dijadikan sebagai tolak ukur kemandirian suatu daerah. Semakin tinggi Pendapatan Asli Daerah dapat menjadi salah satu faktor pendukung dalam meningkatkan sumber daya yang ada di daerah tersebut. Mengingat peran dari Pendapatan Asli Daerah yang cukup penting dalam perekonomian daerah, pada kenyataannya masih banyak ditemukan permasalahan dan kendala yang harus dihadapi dalam pemungutannya di Indonesia.

Dalam penelitian yang dilakukan (Andriani \& Purnawan, 2017), ditemukan hambatanhambatan dalam proses pelaksanaan pemungutan pajak daerah di Provinsi Jawa Tengah yaitu timbul tenggelamnya usaha pemerintah dalam proses pemungutan pajak, masih adanya wilayah yang belum tergali secara optimal, kurangnya kesadaran masyarakat untuk membayar pajak, dan adanya keterbatasan sarana dan prasarana penunjang dalam penyelenggaraan pajak daerah. Berdasarkan permasalahan tersebut pemerintah daerah dituntut untuk mengeluarkan kebijakan-kebijakan terkait dengan pembayaran pajak dan retibusi daerah.

Melalui kompetisi inovasi dari KemenPAN-RB, Pemerintah Kota Surakarta menjadi salah satu pemerintah daerah yang telah melalukan inovasi terhadap pelayanan publik khususnya dalam pembayaran pajak daerah, menurut (Isha'an, 2017) Kota Surakarta dinobatkan menjadi salah satu kota paling inovatif di Indonesia, dengan predikat Pemerintah Kota Terinovatif sepanjang tahun 2017 karena melakukan perubahan dengan sejumlah inovasi dalam pelayanan publik sehingga memberikan kemudahan akses bagi warga untuk mendapatkan pelayanan, serta meningkatkan akuntabilitas karena menjadi lebih transparan. Salah satu instansi pemerintah Kota Surakarta yang berhasil melakukan inovasi pelayanan publik yaitu Badan Pendapatan Pengelolaan Keuangan dan Aset Daerah (BPPKAD) Kota Surakarta, yang mana telah berhasil menciptakan sebuah inovasi yang diberi nama Si Bapak On (Sistem Bayar Pajak Online) yang sekarang telah bertransformasi menjadi Elektronik Pembayaran Pajak Solo Destination (EPPSON). Seperti yang dimuat dalam rri.co.id (Isha'an, 2017), inovasi milik Badan Pendapatan Pengelolaan Keuangan dan Aset Daerah (BPPKAD) Kota Surakarta ini berhasil masuk menjadi 10 besar inovasi terbaik tingkat nasional. Dengan adanya inovasi EPPSON ini diharapkan dapat meningkatkan kesadaran wajib pajak dalam membayar pajak serta untuk meningkatkan transparansi keuangan daerah.

Inovasi EPPSON ini, pertama kali diujicobakan tahun 2017 pada pembayaran Pajak Bumi dan Bangunan Perdesaan dan Perkotaan (PBB P2). Sebelum adanya inovasi ini, apabila akan melakukan pembayaran pajak para wajib pajak harus datang langsung ke kantor BPPKAD Kota Surakarta atau datang ke bank yang bermitra dengan BPPKAD Kota Surakarta guna membayar pajak. Namun dengan adanya inovasi ini dapat membantu mempermudah para wajib melakukan transaksi atau pembayaran pajak dari rumah dengan menggunakan ponsel atau gadged. Transaksi ini dapat dilakukan dengan mengunduh aplikasi "Solo Destination" melalui Play Store. Sistem pembayaran pajak online ini dinilai paling cepat dan mudah. Sebab wajib pajak (WP) tidak perlu lagi repot mengantre dan membuang waktu di hari kerja. Selain dapat mempermudah wajib pajak dalam melakukan pembayaran 
pajak secara online, inovasi EPPSON ini juga berkontribusi meningkatkan Pendapatan Asli Daerah melalui pemasukan pajak daerah.

\section{Gambar 1}

Laporan Realisasi Anggaran Kota Surakarta Tahun 2019

\begin{tabular}{|c|c|c|c|c|c|c|c|}
\hline No. & Jenis Penerimaan & $\begin{array}{l}2015 \\
(\mathrm{Rp})\end{array}$ & $\begin{array}{l}2016 \\
(\mathrm{Rp})\end{array}$ & \multirow{8}{*}{$\begin{array}{l}\mathbf{E} \\
\mathbf{P} \\
\mathbf{P} \\
\mathrm{S} \\
\mathbf{O} \\
\mathbf{N}\end{array}$} & $\begin{array}{l}2017 \\
(\mathbf{R p}) \\
\end{array}$ & $\begin{array}{l}2018 \\
(\mathbf{R p})\end{array}$ & $\begin{array}{l}2019 \\
(\mathbf{R p})\end{array}$ \\
\hline \multirow{2}{*}{1.} & \multirow{2}{*}{ Pajak Daerah } & 233.085 .404 .386 & 252.052 .998 .369 & & 288.421 .242 .637 & 339.929 .155 .616 & 360.053 .930 .720 \\
\hline & & & & & $14 \%$ & $20 \%$ & $43 \%$ \\
\hline 2. & Retribusi Daerah & 51.234 .923 .568 & 59.650 .828 .203 & & 61.543 .331 .057 & 57.024 .070 .534 & 55.288 .238 .663 \\
\hline 3. & $\begin{array}{l}\text { Hasil Pengelolaan } \\
\text { Kekayaan Daerah yang } \\
\text { Dipisahkan }\end{array}$ & 7.584 .189 .359 & 7.988 .822 .285 & & 20.058 .584 .208 & 12.258 .541 .140 & 13.346 .410 .931 \\
\hline 4. & $\begin{array}{l}\text { Lain-lain Pendapatan } \\
\text { Asli Daerah yang Sah } \\
\end{array}$ & 80.893 .909 .477 & 105.810 .130 .206 & & 157.521 .067 .068 & 115.913 .787 .401 & 117.331 .427 .803 \\
\hline 5. & $\begin{array}{l}\text { Pendapatan Pajak dari } \\
\text { PAD }\end{array}$ & 372.798 .426 .790 & 425.502 .779 .064 & & 527.544 .249 .700 & 525.125 .554 .686 & 546.020 .008 .117 \\
\hline & $\begin{array}{l}\text { Persentase Pajak dari } \\
\text { PAD }(\%)\end{array}$ & $60 \%$ & $69 \%$ & & $83 \%$ & $54 \%$ & $52 \%$ \\
\hline
\end{tabular}

Sumber: BPPKAD Kota Surakarta, 2020

Berdasarkan Laporan Realisasi Anggaran Kota Surakarta tahun 2019 di atas, terjadi peningkatan nominal yang cukup tinggi pada penerimaan Pajak Daerah, terutama dari tahun 2017, 2018 dan 2019 hal ini setelah mulai diterapkan inovasi EPPSON pada tahun 2017. Hal ini dapat dilihat bahwa penerimaan pajak daerah pada tahun 2016 sebesar Rp 252.052.998.369, kemudian setelah diterapkan EPPSON terjadi peningkatan sebesar 14\% menjadi Rp 288.421.242.637 pada 2017. Pada 2018 terjadi kenaikan kembali sebesar Rp 339.929.155.616 yaitu 20\% dari tahun sebelumnya, kemudian pada 2019 mengalami peningkatan yang sangat signifikan sebesar 43\% menjadi Rp 360.053.930.720. Hal ini menunjukkan bahwa dengan mulai diberlakukannya inovasi pembayaran pajak online di Surakarta, ikut andil dalam peningkatan pembayaran pajak daerah dan berpengaruh kepada pendapatan asli daerah Kota Surakarta.

Pemahaman berkenaan dengan tipologi suatu inovasi merupakan kontribusi awal guna meningkatkan pemahaman tentang kompleksitas inovasi (Osborne, 1998). Hal ini diperkuat dengan penjelasan (Walker, Jeanes, \& Rowlands, 2002) yang menyebutkan klasifikasi suatu inovasi akan menjadi dasar untuk memahami ruang lingkup inovasi tersebut. Berdasarkan kedua pendapat tersebut, pemahaman mengenai tipologi inovasi pada pelayanan pajak daerah melalui EPPSON sangat penting, hal ini dikarenakan nantinya dapat menjadi dasar dari pemahaman ruang lingkupnya. Deutsch dalam (Osborne, 1998) juga menyebutkan bahwa pemahaman tentang tipologi berguna untuk membantu dalam hal manajemen yang lebih baik ke depannya. Meskipun masih dianggap kompleks, beberapa ahli mencoba merumuskan tipologi inovasi. Menurut Mulgan \& Alburry dalam (Muluk, 2008) bentuk tipologi inovasi yaitu, inovasi produk, inovasi proses pelayanan, inovasi metode, inovasi strategi/kebijakan dan inovasi sistem pelayanan.

Selanjutnya (Windrum \& Koch, 2008) menyebutkan bahwa inovasi memiliki taksonomi antara lain, inovasi pelayanan, inovasi delivery layanan, inovasi administrasi dan organisasi, inovasi konseptual, inovasi kebijakan dan inovasi sistemik. (Perry, 2010) juga mengidentifikasikan tipologi inovasi berdasarkan dari beberapa penggolongan tipologi inovasi menurut para ahli lainnya menjadi 6 (enam) dimensi. Penggolongan ini didasarkan dari perbandingan satu persatu atas kesamaan dan perbedaan pendapat ahli lain tentang tipologi inovasi. Penggolongan tipologi inovasi menurut (Perry, 2010) antara lain, inovasi 
produk, inovasi pelayanan, inovasi proses, inovasi konseptual inovasi kebijakan dan inovasi sistemik. Berdasarkan pemaparan beberapa pendapat ahli tentang tipologi inovasi di atas, peneliti memilih teori tipologi inovasi menurut (Perry, 2010) untuk menganalisis hasil penelitian. Hal ini karena teori tersebut merupakan hasil identifikasi dari beberapa teori tipologi inovasi menurut para ahli sebelumnya, serta terdapat kriteria yang jelas dari masingmasing dimensi. Alasan lain yaitu masih minimnya penelitian yang menggunakan teori tipologi inovasi tersebut.

Berdasarkan latar belakang di atas, peneliti tertarik untuk melakukan penelitian lebih lanjut mengenai tipologi inovasi pelayanan pajak daerah online melalui EPPSON di Badan Pendapatan Pengelolaan Keuangan dan Aset Daerah (BPPKAD) Kota Surakarta. Hasil dari penelitian ini diharapkan dapat menjadi masukan dan pertimbangan bagi Badan Pendapatan Pengelolaan Keuangan dan Aset Daerah (BPPKAD) Kota Surakarta dalam pembuatan keputusan yang berhubungan dengan peningkatan inovasi pelayanan pajak daerah secara online melalui EPPSON.

\section{Metode Penelitian}

Metode yang digunakan dalam penelitian ini adalah deskriptif kualitatif. Lokasi pada penelitian ini yaitu Kota Surakarta lebih khususnya dilakukan di Badan Pendapatan Pengelolaan Keuangan dan Aset Daerah (BPPKAD) Kota Surakarta karena BPPKAD Kota Surakarta merupakan instansi pemerintah yang memiliki kewenangan dalam pengembangan serta pengelolaan inovasi EPPSON di Surakarta. Data yang dibutuhkan dalam penelitian ini yaitu data primer dan data sekunder. Teknik pengumpulan data menggunakan metode wawancara, observasi dan dokumnetasi. Dalam pemilihan informan, peneliti menggunakan teknik purposive sampling yaitu memilih informan yang dianggap mengetahui seluk beluk mengenai inovasi EPPSON. Validitas data yang digunakan yaitu triangulasi sumber, yang dilakukan dengan cara mengecek informasi atau data yang diperoleh dari hasil wawancara dengan pihak BPPKAD selaku penyedia layanan dengan wajib pajak selaku pengguna layanan. Teknik analisis data yang dalam penelitian ini yaitu dengan menggunakan analisis data model interaktif, yang terdiri dari reduksi data, penyajian data dan penarikan kesimpulan.

\section{Hasil dan Pembahasan}

Dalam meningkatkan kualitas pelayanan instansi pemerintah dituntut untuk selalu menghasilkan inovasi-inovasi baru guna memenuhi kebutuhan masyarakat yang semakin kompleks. Salah satu inovasi yang telah dilakukan oleh Badan Pendapatan Pengelolaan Keuangan dan Aset Daerah Kota Surakarta yaitu EPPSON (Elektronik Pembayaran Pajak Solo Destination). EPPSON merupakan salah satu fitur yang dikembangkan BPPKAD Kota Surakarta yang bekerja sama dengan pihak Diskominfo Kota Surakarta. Layanan EPPSON ini dapat digunakan dengan mendownload aplikasi "Solo Destination" melalui Playstore maupun Appstore yang ada di smartphone. Pelaksanaan EPPSON diatur dalam Peraturan Walikota Surakarta No 21 Tahun 2017 tentang Tata Cara Pelaksanaan Sistem Online atas data transaksi usaha wajib pajak dalam rangka pengawasan pembayaran daerah. Dengan hadirnya EPPSON ini diharapkan mampu mempermudah wajib pajak dalam melakukan transaksi pembayaran dan pelayanan pajak daerah serta meningkatkan kepercayaan wajib pajak terhadap pemerintah dalam hal ini BPPKAD Kota Surakarta karena setiap transaksi yang terjadi akan langsung masuk ke database BPPKAD Kota Surakarta sehingga mengurangi interaksi yang memungkinkan terjadinya penyelewengan. 
Inovasi EPPSON pertama kali diterapkan pada tahun 2017 hanya untuk pelayanan Pajak Bumi dan Bangunan, namun setelah adanya pembaharuan pada tahun 2018 EPPSON sudah mampu melayani pajak daerah lainnya. Dalam pengembangan EPPSON ini, muncul fitur baru dalam EPPSON yaitu E-SPTPD (Elektronik Surat Pemberitahuan Tagihan Pajak Daerah). Fitur E-SPTPD dalam EPPSON ini tidak ditujukan untuk seluruh pajak daerah, melainkan hanya untuk pajak hotel, pajak restoran, pajak hiburan dan pajak parkir. Melalui fitur E-SPTPD ini pihak wajib pajak bisa langsung menghitung jumlah pajaknya sendiri dan melaporkan data transaksi usahanya melalui online.

Hasil dari penelitian ini dianalisis berdasarkan teori tipologi inovasi menurut (Perry, 2010) yang terdiri 6 (enam) dimensi yaitu, inovasi produk, inovasi pelayanan, inovasi proses, inovasi konseptual, inovasi kebijakan dan inovasi sistemik. Pembahasan mengenai tipologi inovasi dalam penelitian ini dipaparkan berdasarkan hasil wawancara dengan pihak pelaksana inovasi pelayanan pajak daerah melalui EPPSON yakni Badan Pendapatan Pengelolaan Keuangan dan Aset Daerah Kota Surakarta dan wajib pajak daerah selaku pengguna layanan EPPSON. Hasil yang ditemukan dalam penelitian ini yaitu:

\section{Inovasi Produk}

Menurut (Perry, 2010), inovasi produk yaitu pembaharuan dalam penyediaan layanan maupun produk, selain itu inovasi produk adalah hasil dari suatu organisasi. Inovasi produk memiliki kriteria penentuan, antara lain: (a) Inovasi total, yakni berfokus kepada penyediaan pelayanan baru untuk pengguna baru; (b) Inovasi ekspansi, yakni berfokus kepada penyebaran ke pengguna oleh organisasi publik; (c) Inovasi evolusi, yakni penyediaan pelayanan baru bagi pengguna saat ini. Berdasarkan hasil wawancara dengan beberapa informan ditemukan informasi sebagai berikut.

Inovasi total, dalam penelitian ini ditunjukkan dalam pelayanan pajak daerah melalui EPPSON termasuk produk inovasi baru yang dikeluarkan oleh Badan Pendapatan Pengelolaan Keuangan dan Aset Daerah Kota Surakarta, yang mana produk inovasi ini merupakan salah satu fitur dalam aplikasi "Solo Destination" yang dapat diakses menggunakan smartphone. Inovasi EPPSON ini diterapkan sejak tahun 2017 oleh Badan Pendapatan Pengelolaan Keuangan dan Aset Daerah Kota Surakarta ditujukan untuk seluruh wajib pajak yang tinggal atau memiliki tempat usaha di Kota Surakarta dan ingin mendapatkan pelayanan secara online dalam kewajiban pajak daerah mereka.

Inovasi ekspansi, upaya untuk memperkenalkan inovasi ini, Badan Pendapatan Pengelolaan Keuangan dan Aset Daerah Kota Surakarta melakukan sosialisasi kepada wajib pajak melalui berbagai cara, yaitu penyebaran brosur, banner, video tron, berita media cetak dan online, menu-menu pilihan di bank mitra, kemudian disampaikan juga dalam perkumpulan rutin warga dan perkumpulan rutin antara Badan Pendapatan Pengelolaaan Keuangan dan Aset Daerah Kota Surakarta dengan wajib pajak, serta penyebaran informasi secara tatap muka antar individu.

Inovasi evolusi, penyediaan produk inovasi EPPSON ini juga didasarkan pada kebutuhan masyarakat saat ini, dimana masyarakat tidak perlu repot-repot antre dan dapat mempermudah petugas pajak dalam memantau pemasukan dari pajak daerah di Kota Surakarta. Namun dengan adanya perkembangan pelayanan, tidak semua wajib pajak yang dapat mengakses pelayanan secara online karena perlu adanya daya dukung materi yang menunjang dan pengetahuan terhadap perkembangan teknologi. 


\section{Inovasi Pelayanan}

Menurut (Perry, 2010), inovasi pelayanan berkaitan dengan inovasi produk, yakni pembaharuan produk yang mencakup pada desain dan fitur dalam hal interaksi dengan pengguna layanan. Pada inovasi pelayanan mempunyai kriteria penentuan yaitu pengiriman pelayanan. Pengiriman pelayanan yang dimaksud yaitu peningkatan yang dilakukan oleh organisasi dalam hal pembaharuan model berinteraksi dengan pengguna layanan yang berfokus pada perubahan desain dan produk layanan. Berdasarkan hasil wawancara dengan beberapa informan ditemukan informasi sebagai berikut.

Sebelum diterapkannya pelayanan pajak daerah melalui EPPSON, pihak Badan Pendapatan Pengelolaan Keuangan dan Aset Daerah Kota Surakarta juga telah melakukan peningkatan pelayanan kepada wajib pajak daerah khususnya untuk Pajak Bumi dan Bangunan melalui sistem jemput bola yang disebut dengan "Safari PBB". Dengan adanya Safari PBB ini diharapkan dapat meningkatkan kesadaran wajib pajak untuk melakukan kewajibannya dalam membayar pajak. Hal ini karena Pajak Bumi dan Bangunan merupakan pajak daerah dengan pemasukan tertinggi diantara pajak daerah yang lain, disisi lain juga Pajak Bumi dan Bangunan merupakan pajak daerah dengan piutang tertinggi di Kota Surakarta. Kemudian setelah dilakukan pengembangan lebih lanjut oleh Badan Pendapatan Pengelolaan Keuangan dan Aset Daerah Kota Surakarta serta didukung dengan adanya kerja sama dengan Diskominfo maka munculah inovasi EPPSON yang merupakan salah satu fitur di dalam aplikasi "Solo Destination".

\section{Gambar 2}

Fitur EPPSON

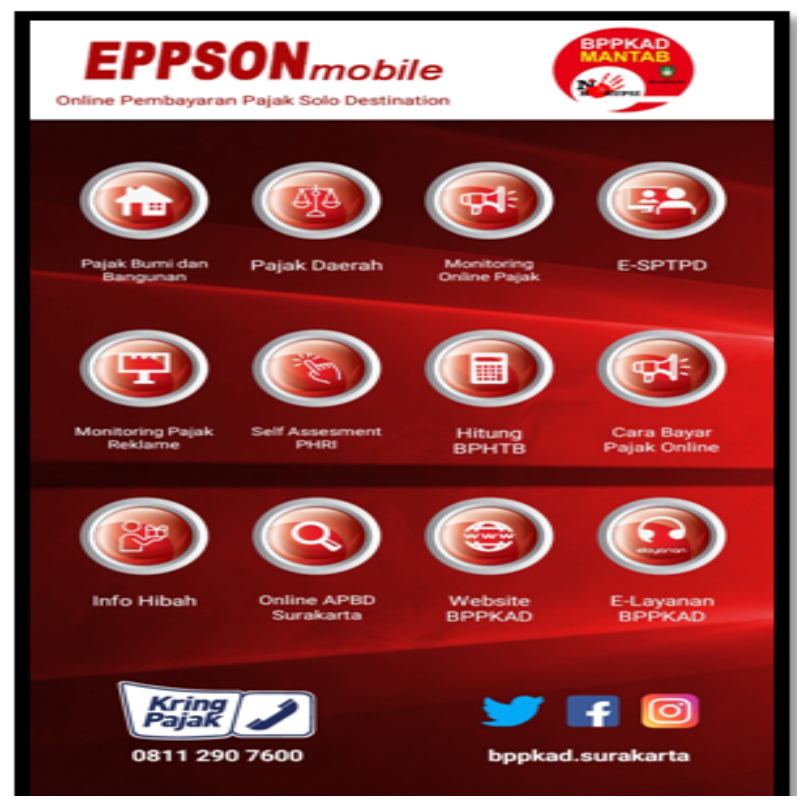

Sumber: Aplikasi Solo Destination, 2020

Terdapat beberapa fitur yang tersedia dalam EPPSON ini, terutama pelayanan pembayaran PBB, penginputan E-SPTPD, dan juga dapat memantau laporan pajak daerah Kota Surakarta secara online. Untuk penampilan fitur terdapat perbedaan antara tampilan Android dan iOS. Sedangkan secara bahasa dan pilihan menu, wajib pajak pengguna inovasi merasa mudah untuk memahami. 


\section{Inovasi Proses}

Menurut (Perry, 2010), inovasi proses yaitu pembaharuan yang dilakukan oleh suatu organisasi guna mendukung inovasi contohnya dalam pembaharuan prosedur dan struktur organisasi. Inovasi proses memiliki kriteria penentuan antara lain: (a) Marketisasi administrasi, yaitu modifikasi proses pelayanan pada organisasi dalam rangka meningkatkan kecepatan pelayanan; (b) Organisasional, yaitu pembaharuan struktur dalam organisasi dan koordinasi dengan karyawan guna mendukung produk pelayanan. Berdasarkan hasil wawancara dengan beberapa informan ditemukan informasi sebagai berikut.

Marketisasi administrasi, Badan Pendapatan Pengelolaan Keuangan dan Aset Daerah Kota Surakarta melakukan pembaharuan prosedur pada pelayanan pajak daerah melalui diciptakannya inovasi EPPSON untuk memudahkan dan meningkatkan pelayanan. Prosedur pelayanan yang sebelumnya masih bersifat manual dimana wajib pajak harus datang langsung ke kantor Badan Pendapatan Pengelolaan Keuangan dan Aset Daerah Kota Surakarta, kemudian mengambil nomor antrean, dan harus membawa berkas-berkas yang diperlukan dalam proses pembayaran pajak daerah. Sedangkan setelah adanya inovasi palayanan pajak daerah melalui EPPSON, wajib pajak yang hendak melakukan proses pembayaran pajak dapat dilakukan dari rumah atau dari tempat usahanya langsung dengan melalui ATM, sms banking, internet banking, mobile banking atau melalui teller.

Gambar 3

Alur Layanan Pajak Bumi dan Bangunan

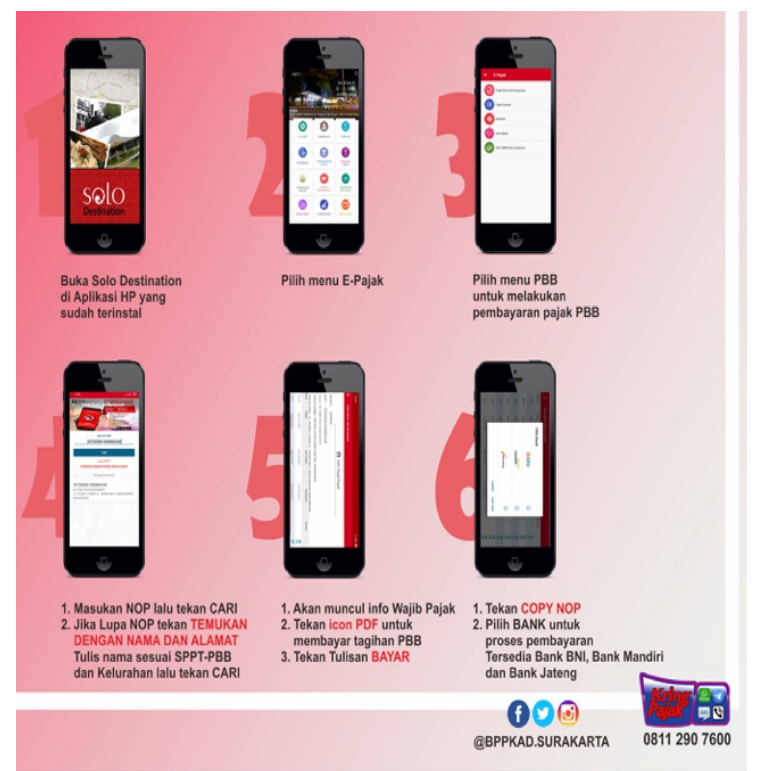

Sumber: BPPKAD Kota Surakarta, 2020

Berdasarkan gambar di atas, bagi wajib pajak PBB hanya tinggal membuka fitur EPajak di aplikasi "Solo Destination", lalu pilih option Pajak Bumi dan Bangunan kemudian tinggal memasukan Nomor Objek Pajak (NOP). Apabila wajib pajak lupa NOP miliknya, maka dapat memasukkan nama dan alamat tempat tinggal yang ingin dibayarkan pajak bumi dan bangunannya. Kemudian klik pilihan bayar, maka akan muncul E-Billing atau kode bayar. Sedangkan untuk pajak daerah lain dalam hal ini pajak restoran, pajak hotel, pajak parkir, dan pajak hiburan, dapat membuka fitur E-SPTPD dan masukkan password serta 
username dari wajib pajak. Kemudian mengisi beberapa data terkait rincian pajak yang harus dibayarkan dan nantinya setelah selesai akan mendapatkan E-Billing atau kode bayar yang nantinya digunakan sebagai kode pembayaran di bank.

Dari pihak wajib pajak yang telah menggunakan inovasi ini pun merasa dimudahkan dalam proses pembayaran pajak daerahnya.

"Memudahkan ya, kalau dulu kan biasanya ke kantor BPPKAD di Koorwil itu di Jebres. Terus kita harus bawa uang tunai tapi kan sekarang kita bisa input sendiri, terus kita tinggal bayarnya lewat bank. Enaknya ya kita bisa input sendiri dan lebih aman nggak perlu bawa uang tunai." (Wajib pajak daerah, hasil wawancara tanggal 1 Desember 2020).

Organisasional, Meskipun terjadi pembaharuan prosedur pelayanan, pihak Badan Pendapatan Pengelolaan Keuangan dan Aset Daerah Kota Surakarta tidak melakukan perubahan pada struktur organisasinya. Hal ini karena struktur organisasi seluruh perangkat daerah di Surakarta telah diatur dalam satu peraturan yaitu dalam Peraturan Walikota Surakarta Nomor 27-C Tahun 2016 tentang Kedudukan, Susunan Organisasi, Tugas, Fungsi dan Tata Kerja Perangkat Daerah Kota Surakarta. Sehingga sejauh ini tidak ada perubahan dalam struktur organisasi hanya ada sedikit perubahan pada tata kelola kepegawaian yang ada di Badan Pendapatan Pengelolaan Keuangan dan Aset Daerah Kota Surakarta. Meskipun tidak terjadi perubahan dalam struktur organisasi, tetap ada pembaharuan terkait tata kelola pegawai yang sebelumnya banyak yang ditempatkan di lapangan kemudian dengan hadirnya inovasi baru ini pegawai tersebut menjadi diperbantukan kepada bidang lain yang membutuhkan banyak sumber daya manusia.

\section{Inovasi Konseptual}

Menurut (Perry, 2010), inovasi konseptual yaitu adanya pembaharuan atau perubahan yang dilakukan suatu organisasi dalam hal misi, tujuan, dan prinsip yang menjadi dasar pelayanan. Selain itu perubahan pola pikir pada karyawan, yang mana dilakukan sejalan dengan penggunaan konsep baru. Berdasarkan hasil wawancara dengan beberapa informan ditemukan informasi sebagai berikut.

Dalam hal misi dan tujuan dari Badan Pendapatan Pengelolaan Keuangan dan Aset Daerah Kota Surakarta tidak terjadi perubahan baik yang masih menggunakan sistem manual, jemput bola, maupun online. Misi yang dipegang teguh oleh Badan Pendapatan Pengelolaan Keuangan dan Aset Daerah Kota Surakarta yaitu diharapkan dengan adanya inovasi baru semakin memudahkan masyarakat dalam melakukan pembayaran serta dapat meningkatkan kesadaran wajib pajak dalam membayar pajak daerahnya. Kemudian untuk tujuan yang diharapkan dari adanya inovasi baru EPPSON yang bersifat online ini, yaitu agar dapat meningkatkan kepercayaan wajib pajak kepada petugas pajak berkaitan dengan transparansi aliran pajak daerah.

Meskipun tidak terjadi perubahan dalam hal misi dan tujuan, tentu terjadi perubahan pola pikir dari karyawan Badan Pendapatan Pengelolaan Keuangan dan Aset Daerah Kota Surakarta. Yaitu perubahan pola pikir pada pemberian layanan dari yang sebelumnya manual menjadi digital. Dengan adanya perubahan pola pikir karyawan, tentunya mampu mendukung peningkatan kualitas pelayanan yang diberikan kepada masyarakat selaku wajib pajak. 


\title{
Inovasi Kebijakan
}

Menurut (Perry, 2010), inovasi kebijakan berkaitan dengan inovasi konseptual, yang mana ditandai dengan adanya strategi yang digunakan untuk mendukung inovasi konseptual. Maksudnya terdapat strategi yang digunakan untuk mencapai misi, tujuan, dan pola pikir karyawan yang telah diperbarui.

Berdasarkan uraian inovasi konseptual sebelumnya, tidak terjadi pembaharuan dalam hal misi dan tujuan yang dilakukan oleh Badan Pendapatan Pengelolaan Keuangan dan Aset Daerah Kota Surakarta, namun terdapat perubahan dalam pola pikir karyawan dalam rangka peningkatan kualitas pelayanan bagi masyarakat selaku wajib pajak. Strategi yang dilakukan oleh Badan Pendapatan Pengelolaan Keuangan dan Aset Daerah Kota Surakarta guna mendukung perubahan pola pikir karyawan dilakukan pelatihan-pelatihan internal yang bertujuan untuk meningkatkan keterampilan dan pengetahuan pegawai BPPKAD dalam pelayanan berbasis teknologi. Pelatihan ini sudah dilakukan beberapa bulan sebelum inovasi EPPSON mulai diluncurkan.

Selain strategi dalam perubahan pola pikir karyawan, Badan Pendapatan Pengelolaan Keuangan dan Aset Daerah Kota Surakarta juga memiliki strategi lain terkait sosialisasi guna mendukung peningkatan kesadaran pajak daerah di Kota Surakarta. Yaitu dengan melalui pengadaan undian berhadiah bagi seluruh wajib pajak daerah Kota Surakarta yang tertib membayar kewajiban pajaknya. Melalui adanya pengadaan undian berhadiah ini diharapkan mampu menambah kesadaran masyarakat tentang pentingnya membayar pajak tepat waktu.

\begin{abstract}
"Untuk meningkatkan kesadaran membayar pajak kita juga ada pengadaan undian berhadiah mbak nggih. Jadi bagi wajib pajak yang tertib dan tepat waktu dalam membayar pajak kalau beruntung bisa memenangkan hadiah yang sudah kami siapkan nggih. Hadiahnya ada mobil, motor juga. Kan dengan begitu masyarakat bisa menambah semangat untuk membayar pajak kan mbak.” (Kepala Bidang Penagihan, hasil wawancara tanggal 19 Oktober 2020).
\end{abstract}

\section{Inovasi Sistemik}

Menurut (Perry, 2010), inovasi sistemik yakni adanya kerja sama dengan aktor atau pihak lain di luar organisasi dalam suatu inovasi. Kerja sama yang dilakukan yaitu berdasarkan basis pengetahuan organisasi yang dibutuhkan guna mendukung peningkatan produk pelayanan, misalnya kerja sama yang dilakukan antara organisasi publik dan organisasi privat.

Dalam pelaksanaan inovasi EPPSON, Badan Pendapatan Pengelolaan Keuangan dan Aset Daerah Kota Surakarta melakukan kerjasama dengan pihak lain diluar organisasi berkaitan dengan jaringan. Karena EPPSON termasuk fitur di dalam aplikasi "Solo Destination", tentu saja pihak Badan Pendapatan Pengelolaan Keuangan dan Aset Daerah Surakarta bekerjasama dengan Dinas Komunikasi, Informatika, Statistik dan Persandian (Diskominfo SP) Kota Surakarta dalam hal jaringan pemantauan data secara real time di dalam aplikasi. Kemudian untuk jaringan pajak daerah lain terkait mesin Terminal Mobile Device (TMD) pihak Badan Pendapatan Pengelolaan Keuangan dan Aset Daerah Kota Surakarta bekerjasama dengan Telkom Indonesia dan Finnet, yang mana TMD tersebut terpasang di restoran maupun hotel guna mencatat transaksi secara langsung. Kemudian terkait proses transaksi pembayaran, Badan Pendapatan Pengelolaan Keuangan dan Aset Daerah Kota Surakarta bekerjasama dengan satu bank persepsi yakni Bank Jateng dan 5 
(lima) bank mitra, yaitu Bank Mandiri, BNI, BTN, BCA dan BRI. Untuk pilihan pembayarannya bisa dilakukan melalui mobile banking, sms banking, internet banking, ATM atau pun teller.

Sedangkan kendala yang masih ditemui dalam pelaksanaan inovasi pelayanan pajak daerah melalui EPPSON ini yaitu terjadi permasalahan dalam hal jaringan dan sistem. Untuk masalah jaringan, biasanya diakibatkan karena sinyal yang kurang kuat untuk mengakses aplikasi "Solo Destination" dan permasalahan pada sistem internal dari pihak wajib pajak yang masih belum terintegrasi dengan sistem pencatatan omzet secara manual. Lalu kendala yang lain yaitu permasalahan jaringan yang lemah untuk mengintegrasikan jaringan EPPSON dengan pihak bank mitra terkait dalam pelayanan pembayaran pajak PBB melalui Safari PBB.

\section{Simpulan}

Berdasarkan analisis dari hasil penelitian mengenai tipologi inovasi pelayanan pajak daerah melalui EPPSON dapat diketahui bahwa dari 6 (enam) dimensi tipologi inovasi menurut (Perry, 2010), terdapat 4 (empat) dimensi yang telah memenuhi kriteria penentuan sedangkan 2 (dua) dimensi yang lain hanya memenuhi sebagian kriteria penentuan. 4 (empat) dimensi yang telah memenuhi seluruh kriteria yaitu, inovasi produk, inovasi pelayanan, inovasi kebijakan dan inovasi sistemik. Sedangkan untuk 2 (dua) dimensi yang hanya memenuhi sebagian kriteria penentuan yaitu, inovasi proses dan inovasi konseptual.

Secara garis besar dengan adanya inovasi EPPSON ini telah mampu meningkatkan pendapatan asli daerah Kota Surakarta dari tahun ke tahun semenjak diterapkannya inovasi EPPSON pada tahun 2017. Namun masih ada beberapa saran yang dapat penulis berikan dan diharapkan dapat membantu Badan Pendapatan Pengelolaan Keuangan dan Aset Daerah Kota Surakarta dalam mengembangkan inovasi ini. Bagi pihak BPPKAD Kota Surakarta masih diperlukan pengembangan lebih lanjut dalam fitur EPPSON terutama bagi pajak daerah lain yang belum bisa melakukan transaksi pembayaran langsung dalam satu aplikasi tersebut. Selain itu, diharapkan pihak BPPKAD Kota Surakarta dapat memaksimalkan penerapan ESPTPD bagi seluruh pemilik usaha di Kota Surakarta, hal ini karena masih banyak usahausaha di Kota Surakarta yang masih menggunakan sistem lapor pajak secara manual karena keterbatasan sistem teknologi yang belum memadai. 


\section{Referensi}

Andriani, N., \& Purnawan, A. (2017). Eksistensi Pengaturan Pajak Daerah Dalam Rangka Meningkatkan Pendapatan Asli Daerah di Pemerintah Provinsi Jawa Tengah. Jurnal Hukum Khaira Ummah , 12 (1), 1-8.

Horota, P., Riani, I. A., \& Marbun, R. M. (2017). Peningkatan Pendapatan Asli Daerah Dalam Rangka Otonomi Daerah Melalui Potensi Pajak dan Retribusi Daerah di Kabupaten Jayapura. Jurnal Kajian Ekonomi dan Keuangan Daerah , 2 (1), 1-33.

Isha'an, M. (2017, Desember). Daerah: Solo Raih Penghargaan Kota Paling Inovatif 2017. Retrieved Desember 13, 2019, from rri.co.id: http://rri.co.id/post/berita/469742/daerah/solo_raih_penghargaan_kota_paling_inovatif _2017.html

Muluk, K. (2008). Knowledge Management Kunci Sukses Inovasi Pemerintah Daerah. Malang: Bayu Media.

Osborne, S. T. (1998). Naming the Beast: Defining and Classifying Service Innovations in Social Policy. Human Relations, 51 (9), 1133-1153.

Perry, K. A. (2010). Innovation in the 'Public Sector' : putting it into Perspective. Retrieved September 27, 2020, from Denmark: Department of Communication, Business and Information Technologies: Roskilde University: https://www.ucviden.dk/portal/en/publication/innovation-in-the-publicsector(b8e7d3d5-682d-4967-aaa5-66c5cb12c241).html

Walker, R. M., Jeanes, E., \& Rowlands, R. (2002). Measuring Innovation - Applying the Literature - Based Innovation Output Indicator to Public Services. Public Administration , 80 (1), 2001-2014.

Windrum, P., \& Koch, P. (2008). Innovation in Public Sector Service : Entrepreneurship, Creativity, and Management. Cheltanham, UK: Edward Elgar Publishing Limited. 